\title{
EFFECT OF HEXANE FRACTION FROM PAPAYA (CARICA PAPAYA L.) MALE FLOWER ON CELL CYCLE OF COLON ADENOCARCINOMA (WIDR) CELL AND ITS COMBINATION INDEX WITH DOXORUBICIN
}

\author{
YUSNITA $Y^{1 *}$, MASFRIA $\mathbf{M}^{2}$, ROSIDAH $\mathbf{R}^{1}$, IKSEN I ${ }^{2}$
}

${ }^{1}$ Department of Pharmacology, Faculty of Pharmacy, Universita Sumatera Utara, Medan, Indonesia. ${ }^{2}$ Department of Pharmaceutical Chemistry, Faculty of Pharmacy, Universitas Sumatera Utara, Medan, Indonesia. Email: ita_apt79@yahoo.com

Received: 30 January 2018, Revised and Accepted: 29 March 2018

\section{ABSTRACT}

Objective: This study aimed to evaluate the effects of papaya (Carica papaya L.) male flower hexane fraction (PHF) on cell cycle of colon adenocarcinoma (WiDr) cell and its combination index (CI) with doxorubicin.

Methods: Flow cytometer and the CI were used to show the PHF on cell cycle of colon adenocarcinoma (WiDr) cell and to calculate the synergism potential, respectively.

Result: The result showed that the PHF giving inhibition on cell cycle of colon adenocarcinoma (WiDr) cell in G0-G1, S, G2-M phase. Furthermore, the combination of PHF with doxorubicin in colon adenocarcinoma (WiDr) cell gave a strong synergistic effect with optimal concentration of $8 \mu \mathrm{g} / \mathrm{ml}-50$ nM (PHF-Doxorubicin) with the IC score lower than 1.

Conclusion: This study provides evidence that PHF could be a new potential co-chemotherapeutic agent with doxorubicin on colon adenocarcinoma cell.

Keywords: Papaya male flower, Doxorubicin, Combination index, Cell cycle, WiDr.

(C) 2018 The Authors. Published by Innovare Academic Sciences Pvt Ltd. This is an open access article under the CC BY license (http://creativecommons. org/licenses/by/4. 0/) DOI: http://dx.doi.org/10.22159/ajpcr.2018.v11i7.25023

\section{INTRODUCTION}

Cancer is a disease in which disorder occurs in the normal processes of cell division, which are controlled by the genetic material (DNA) of the cell. Viruses, chemical carcinogens, chromosomal rearrangement, tumor suppressor genes, or spontaneous transformation have been implicated in the causes of cancer. Cancer is the leading cause of mortality worldwide. According to the cancer reports published by the World Health Organization and the World Cancer Research Fund, the incidence of cancer is still increasing, especially due to diet, environment, and carcinogenic virus infections [1,2].

The World Health Organization estimates that about $10 \%$ of deaths in developing countries are caused by cancer-related illnesses and about 10 million new cancer cases are reported every year [3]. This number is projected to increase to 12.0 million in 2030 . Cancers may be caused in one of three ways, namely, incorrect diet, genetic predisposition, and through the environment. At least $35 \%$ of all cancers worldwide are caused by an incorrect diet, and in the case of colon cancer, diet may account for $80 \%$ of the cases. When one adds alcohol and cigarettes to their diet, the percentage may increase to $60 \%$. Genetic predisposition to cancer lends itself to $\sim 20 \%$ of cancer cases, thus leaving the majority of cancers being associated with a host of environmental carcinogens [4].

Cancer is a disease characterized by uncontrolled cell growth [5]. In most cases, these cells divide uncontrollably forming lumps or tumors and consequently interfering with the normal functioning of the cells. In leukemia, the cancerous cells do not form lumps or tumors but rather causes cell deformation, resulting in interference with normal blood functions. Not all tumors are cancerous. Cells of cancerous tumors differ from cells of non-cancerous tumors in their ability to relocate to other parts of the body and invade healthy cells. Cancerous uncontrolled cell division is primarily due to oxidative cell damage caused by free radicals. Free radicals are acquired from the environment through exposure to cigarette smoke and other products of incomplete combustion and ultraviolet radiation and are also produced in the body during the normal process of food breakdown [6].

In Indonesia, colon and rectal cancer are ranked fourth of cancer deaths after lung, liver, and stomach cancer every year [7]. Therefore, proper prevention and treatment efforts are needed to reduce the incidence of death from colon cancer. Diet with high consumption of antioxidant-rich fruits and vegetables significantly reduces the risk of many cancer diseases, suggesting that confident antioxidants could be effective agents for the inhibition of cancer spread [8]. Papaya (Carica papaya L.) male flower is a potential chemopreventive agent. The previous study showed that the hexane fraction of papaya male flower has a good antioxidant activity $\left(\mathrm{IC}_{50}: 100.81 \pm 1.180 \mu \mathrm{g} / \mathrm{ml}\right)$. Cytotoxic study using MTT assay on colon adenocarcinoma (WiDr) cell showed that PHF has a good $\mathrm{IC}_{50}$ value on cell viability ( $\mathrm{IC}_{50}: 64.105 \mu \mathrm{g} / \mathrm{ml}$ ) [9]. This result indicated that hexane fraction could suppress the growth of WiDr cell. Therefore, the aim of the present study was to continue the investigation on cell cycle of colon adenocarcinoma (WiDr) cell and its combination index (CI) with doxorubicin.

\section{METHODS}

\section{Preparation of plant material and hexane fraction}

Fresh PHF was collected from a local area of Porsea district (North Sumatra, Indonesia) and authenticated by Herbarium Medanense University of Sumatera Utara. Voucher specimen was collected and deposited in the Pharmacognosy Laboratory, Faculty of Pharmacy, University of Sumatera Utara.

The extraction was done by percolation method using ethanol solvent. $200 \mathrm{~g}$ of powdered PHF are percolated in $1 \mathrm{~L}$ ethanol solvent $24 \mathrm{~h}$, then filtered, and do it continuously until the filtrate obtained is clear and colorless. $10 \mathrm{~g}$ of concentrated ethanolic extract was then suspended in water and partitioned using hexane solvent to the PHF $[10,11]$. 
Flow cytometry assay

WiDr cell with a density $5.10^{5}$ cells/well was transferred into 6-well plate and then incubated for $24 \mathrm{~h}$. At the end of incubation time, all the cells both adherent and floating are harvested using trypsin-EDTA $0.25 \%$ in the conical tube. The cells were washed thrice with cold phosphate-buffered saline (PBS) and resuspended in PBS containing propidium iodide. The samples were then analyzed using flow cytometer. Percentage of cells in each stage of the cell cycle (sub G1, G1, S, and G2/M) was calculated using CellQuest program [12-14].

\section{CI assay}

The $\mathrm{CI}$ is a quantitative representation of pharmacological interaction between two drugs. For this purpose, WiDr cells were incubated with doxorubicin and PHF alone and in combination. WiDr cells were treated with increasing doses of PHF $(8-32 \mu \mathrm{g} / \mathrm{ml})$ and doxorubicin (25-200 nM). Cell growth inhibition was detected by applying MTT assay. CI value of 1 shows an addictive effect, while $\mathrm{CI}<1$ or CI>1 exhibit synergism or antagonism, respectively $[15,16]$.

\section{RESULTS}

\section{Flow cytometry assay}

Cell cycle line analysis using flow cytometry of WiDr cells showed that the treatment using PHF induced Go-G1, S, and G2-M phase. Fig. 1 shows the result of flow cytometry assay on cell cycle line.

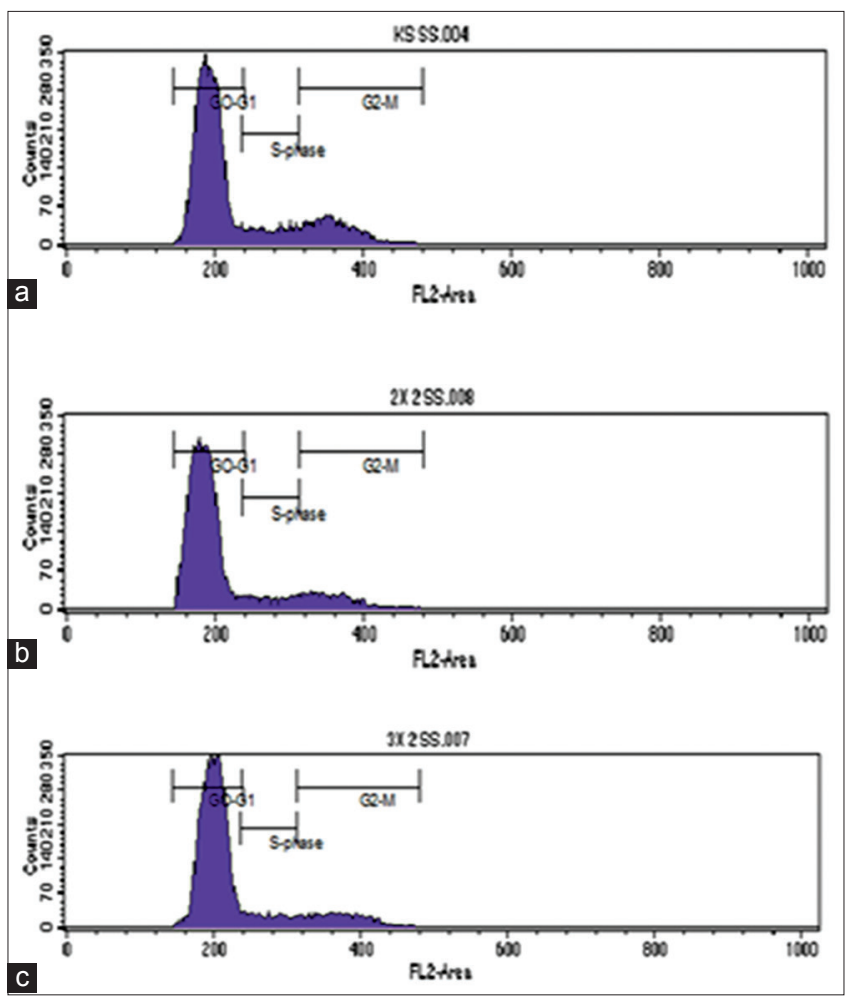

Fig. 1: Cell cycle analysis using flowcytometry. (a) WiDr control cell; (b) 2. IC ${ }_{50}$ on control cell; (c) 3. IC s0 $_{\text {on control cell }}$

Table 1. Synergistic effects of combination of PHF and doxorubicin on WiDr cells

\begin{tabular}{lllll}
\hline PHF $(\mu \mathrm{g} / \mathbf{m l})$ & \multicolumn{5}{l}{ Doxorubicin (nM) } \\
\cline { 2 - 5 } & $\mathbf{2 5}$ & $\mathbf{5 0}$ & $\mathbf{1 0 0}$ & $\mathbf{2 0 0}$ \\
\hline 8 & 0.05 & 0.03 & 0.19 & 0.17 \\
16 & 0.07 & 0.04 & 0.28 & 0.91 \\
24 & 0.47 & 0.13 & 0.39 & 0.66 \\
32 & 0.49 & 0.23 & 0.91 & 4.34 \\
\hline
\end{tabular}

CI assay

Our study showed that a combination of PHF ( $8 \mu \mathrm{g} / \mathrm{ml})$ along with doxorubicin $(50 \mathrm{nM})$ for $24 \mathrm{~h}$ elevated the $\mathrm{CI}$ of 0.03 (Table 1 ).

\section{DISCUSSIONS}

Plants have been demonstrated to be a very viable source of many compounds that have a good beneficial for human life such as anticancer compounds $[17,18]$. This study was conducted using plants which aimed to evaluate the effects of PHF on cell cycle of colon adenocarcinoma (WiDr) cell and its $\mathrm{CI}$ with doxorubicin. Our previous study showed that the PHF has a good antioxidant activity $\left(\mathrm{IC}_{50}: 100.81 \pm 1.180 \mu \mathrm{g} / \mathrm{ml}\right.$ ). Cytotoxic study using MTT assay on colon adenocarcinoma (WiDr) cell showed that PHF has a good $\mathrm{IC}_{50}$ value on cell viability ( $\mathrm{IC}_{50}: 64.105 \mu \mathrm{g} / \mathrm{ml}$ ) [9]. This present study performed the effect of PHF on the cell cycle line and its combination effect with doxorubicin. Cell cycle line analysis of WiDr cells showed that the PHF can induce G0-G1, S, and G2-M phases. The higher doses of PHF, the better result will be obtained. The $\mathrm{CI}$ is a widely accepted qualitative measure of the extent of drug interaction [19]. The CI analysis showed that PHF is suitable and a good co-chemotherapeutic agent with doxorubicin with $\mathrm{CI}$ value is 0.03 .

One of the main possibilities for this good result is that the triterpenoid compounds in PHF are capable of inhibiting topoisomerase enzymes in mammalian cells. There are two classes of topoisomerase enzymes in mammalian cells, Type I which cut and break a single strand of DNA and Type II that cuts and divides double-stranded DNA. Topoisomerase enzyme inhibitors will stabilize topoisomerase and truncated the DNA complexes, which can lead to DNA damage. The presence of DNA damage can lead to the expression of proapoptosis protein so that it can spur apoptosis [20]. Another possibility is because of the high antioxidant activity from the hexane fraction of PHF [21,22].

\section{CONCLUSIONS}

Based on the results, we concluded that PHF has a good potential effect as a co-chemotherapeutic agent for doxorubicin in colon adenocarcinoma (WiDr) cell. These findings indicate the medicinal value of papaya in terms of cancer chemotherapy and chemoprevention.

\section{CONFLICTS OF INTEREST}

We declare that we have no any conflict of interest.

\section{AUTHORS' CONTRIBUTION}

All the authors have contributed equally

\section{ACKNOWLEDGMENTS}

This work was supported by Faculty of Pharmacy, Universitas Sumatera Utara.

\section{REFERENCES}

1. World Health Organization. World Cancer Report 2008. France: IARC; 2008.

2. World Cancer Research Fund. Food, physical activity and the prevention of cancer: A global perspective. USA: America Insititute for Cancer Research; 2007.

3. Chanber BA, Roberts TG. Timeline: Chemotherapy and the war on cancer. Nat Rev Cancer 2005;5:65-72.

4. Wiredu EK, Armah HB. Cancer mortality patterns in Ghana: A 10-year review of autopsies and hospital mortality. BMC Public Health 2006; $6: 1-7$

5. Boyd RF. Little Basic Medical Microbiology. Vol. 05. London: Brown and Company, Inc.; 1995. p. 25.

6. American Cancer Society. Cancer Facts and Figure 2008. USA, Atlanta: American. Cancer Society; 2008.

7. Indonesia Health Ministry. Stop Cancer. Indonesia Department of Health 2015. Indonesia: Indonesia Health Ministry; 2015.

8. Ghasemzadeh A, Jaafar HZ. Antioxidant potential and anticancer 
activity of young ginger (Zingiber officinale Roscoe) grown under different $\mathrm{CO}_{2}$ concentration. J Med Plant Res 2011;5:3247-5.

9. Sianipar MP. Test Activity of Apoptosis Triggers of Papaya Male Flower (Carica papaya L.) on Colon Cancer Cells. Thesis 2017, Faculty of Pharmacy, University of Sumatera Utara; 2017. p. 1-106.

10. Ditjen PO. Indonesia Pharmacopeia. Vol. 4. Jakarta: Indonesia Ministry of Health; 1995. p. 896-8.

11. Basset J, Denney RC, Jeffrey GH, Mendham J. Quantitative Inorganic Chemical Analysis. $4^{\text {th }}$ ed. Jakarta: EGC; 1994.

12. Cancer Chemoprevention Research Centre. In vitro protocol. Indonesia: CCRC; 2008

13. Hasibuan PA, Chrestella J, Satria D. Combination effect of ethylacetate extracts of Plectranthus amboinicus (Lour) Spreng. With doxorubicin against T47D breast cancer cells. Int J Pharm Pharm Sci 2015;7:156-9.

14. Satria D, Furqan M, Hadisahputra S, Rosidah R. Combinational effects of ethylacetate extract of Picria Feel-Terrae Lour and doxorubicin on T47D breast cancer cells. Int J Pharm Pharm Sci 2015;7:73-6.

15. Chavoshi H, Vahedian V, Saghaei S, Bagher M, Pirouzpanah P, Raeisi M, et al. Adjuvant therapy with silibinin improves the efficacy of paclitaxel and cisplatin in MCF-7 breast cancer cells. Asian Pac J Cancer Prev 2017;18 2243-7.

16. Yusnita Y. Anticancer Test Activities of Hexane Fraction from Papaya Male Flower (Carica papaya L.) on Colon Cancer WiDr cell in vitro.
Thesis 2018, Faculty of Pharmacy, University of Sumatera Utara; 2018. p. 1-87.

17. Haro G, Iksen I, Sinaga SM, Nerdy N, Theerachetmongkol S. Protective effects of chives leaves (Allium schoenoprasum L.) infusion against ethylene glycol and ammonium chloride induced nephrolithiasis in rats. J Appl Pharm Sci 2017;7:222-5.

18. Mongelli E, Pampuro S, Coussio J, Salomon H, Ciccia G. Cytotoxic and DNA interaction activities of extracts from medicinal plants used in argentina. J Ethnopharmacol 2000;71:145-50.

19. Wu GS, Lu JJ, Guo JJ, Jia JG, Ming QH, Gan L, et al. Synergistic anti-cancer activity of the combination of dihydroartemisinin and doxorubicin in breast cancer cells. Pharmacol Reports 2013;65:453-9.

20. Setiawati A, Septisetya EP, Wijayanti TR, Rokhama R. Sambung Nyawa Sebagai Agen Kemopreventif. Thesis, Faculty of Pharmacy, University of Gadjah Mada; 2007. p. 1-85.

21. Nisa S, Bibi Y, Waheed A, Zia M, Sarwar S, Ahmed S, Chaudary MF. Evaluation of anticancer activity of Debregeasia Salicifolia extract against estrogen receptor positive cell line. Afr J Biotechnol 2011;10:990-5.

22. Deepika KS, Rama NK, Muthuraman MS, Natesan R, Raj D, Pemaiah B. Evaluation of in vitro anticancer potential of ethanolic extract and different fractions of Caesalpinia bonduc (L) Roxb seeds. Int J Pharm Pharm Sci 2014;6:311-4. 